Joanna Rutkowiak

Olsztyńska Szkoła Wyższa im. Józefa Rusieckiego

\title{
Towarzystwo naukowe w czasach trudnych. Esej na 35-lecie Polskiego Towarzystwa Pedagogicznego
}

Zabiegając o uspołecznianie edukacji, nie uspołeczniliśmy samych siebie.

Tekst ten poświęcam refleksji nad wybranymi działaniami i kierunkami przemian zachodzących w wymienionym okresie w Polskim Towarzystwie Pedagogicznym oraz zarysowi propozycji, jakie perspektywicznie mogłyby ukierunkować aktywność Towarzystwa. Nie jest to narracja obiektywizująca, tylko koleżeńska wypowiedź prowadzona z pozycji uczestniczki wydarzeń z poczuciem współodpowiedzialności za ich treść i bieg. Jej celem jest zainicjowanie dyskusji nad rozwojowymi perspektywami PTP.

Polskie Towarzystwo Pedagogiczne powołano do życia wiosną 1981 roku. Wymieniając tę datę, trzeba jednak pamiętać o działaniach prekursorskich, jak powołanie przez Ewarysta Estkowskiego Polskiego Towarzystwa Pedagogicznego w Poznaniu, w roku 1848, czyli w trudnych czasach rozbiorowych.

Przypomniany sygnał dotyczy wpisania się współczesnego PTP w określoną tradycję Europy, gdzie już od XV wieku zakładano towarzystwa naukowe, początkowo we Włoszech, a następnie w innych krajach. Polska nie miała w tej kwestii opóźnienia - w roku 1489 powołano tutaj Sodalis Litteraria Vistulana, ale punktem przełomowym dla upowszechniania ruchu naukowego było zorganizowanie w roku 1800 Towarzystwa Warszawskiego Przyjaciół Nauk, które ugruntowało instytucje tego typu w polskiej kulturze umysłowej. Od tej pory rozwijały się towarzystwa ogólne bądź specjalistyczne czy terenowe, realizujące swoją działalność albo w warunkach im sprzyjających - a zawsze odnosiły się one do atmosfery prowadzenia poszukiwań badawczych i uprawiania wolnej myśli oraz odpowiedzialności za jej propagowanie, albo w sytuacjach ograniczeń, kiedy towarzystwa wytrwale walczyły o przetrwanie (Bartosik 2013).

Obecnie, według szacunków z roku 2002, działa w kraju około 280 towarzystw naukowych ogólnych, regionalnych, specjalistycznych, naukowo-zawodowych 
i naukowo-technicznych zrzeszających łącznie około 340 tysięcy członków. Oznacza to, że Polskie Towarzystwo Pedagogiczne jest osadzone w rodzinie organizacji pokrewnych duchem, co wzmacnia zasoby energetyczne całego tego środowiska i sprzyja możliwości wzajemnego korzystania z doświadczeń, a nie jest to bez znaczenia w czasach trudnych.

W statutach współczesnych polskich towarzystw naukowych, a zainteresowałam się tymi dokumentami, począwszy od Polskiego Towarzystwa Filozoficznego, a kończąc na statucie Polskiego Towarzystwa Naukowego Silników Spalinowych, przedstawia się ich cele, które dotyczą dwóch zakresów działań:

- uprawiania i popierania badań naukowych przez udział członków towarzystw w rozwoju odpowiednich dyscyplin naukowych;

- propagowania uzyskiwanych wyników, krzewienia myśli, upowszechniania wiedzy $\mathrm{w}$ poczuciu odpowiedzialności, popularyzowania osiągnięć poznawczych zarówno wśród swoich członków, jak i szerokich kręgów społeczeństw.

Nie inaczej zbudowany jest - niedawno zmodyfikowany - statut PTP, w którym zapisano, że: „Celem Towarzystwa jest udział w rozwoju nauk pedagogicznych i popularyzacja ich w kraju i za granicą" (rozdz. II \$10 pkt 1 Statutu Polskiego Towarzystwa Pedagogicznego z 11 maja 2016 roku ze zmianami z 6 czerwca 2017 roku).

Zamysł poprowadzenia refleksji nad 35-letnią aktywnością PTP zamierzam odnieść do wypełniania przez Towarzystwo jego obydwu statutowych zamierzeń z zaakcentowaniem komplikacji realizacyjnych.

Powracając do tytułu niniejszego eseju, powiedzmy, że rok 1981, jako czas powołania Towarzystwa, był dla ówczesnych jego działaczy czasem trudnym i łatwym zarazem. To, co ułatwiało pracę, wynikało z doświadczania „Solidarności” jako wspólnotowego zrywu, sprzyjającego uzyskiwaniu podmiotowych nastawień, doznawania realnego poczucia sprawstwa, a w aspekcie organizacyjnym - rozrastania się i krzepnięcia masowej organizacji społecznej, skutecznie upominającej się o poprawę jakości życia ludzi, w tym także poziomu oświaty. Rodziło to silną motywację do angażowania się w sprawy publiczne, a na co dzień owocowało entuzjazmem, współdziałaniem, zaufaniem, przyjaźnią, optymizmem, energią, nadzieją w wymiarze indywidualnym i społecznym, a w przypadku pedagogów - również wizją naprawiania stanu edukacji z nasilaniem jej prorozwojowych potencjałów.

Natomiast trudności czasów polegały na: konieczności przezwyciężania układu systemowego, działania w warunkach braku wyraźnych perspektyw i środków; chwiejności sytuacji; pojawianiu się nieoczekiwanych zagrożeń, z których najtrudniejszym był stan wojenny; obciążeniu siermiężną codziennością, a także świadomością tego, jak wielka i zupełnie nowa praca jest przed nami.

Muszę wyznać, że nie w tamtych gorących dniach, ale dopiero później doceniłam, jak ludzie działający wówczas na rzecz powołania PTP, a trzeba wymienić co najmniej kilku profesorów: Bogdana Suchodolskiego, Wincentego Okonia, Mikołaja Kozakiewicza, Zbigniewa Kwiecińskiego, zdołali przezwyciężyć trudności, wykorzystać błysk i przesmyk wolności między podpisaniem porozumień 
sierpniowych w roku 1980 a zapadnięciem stanu wojennego w grudniu 1981 roku dla zrealizowania tego niezwykle ważnego przedsięwzięcia.

Wstępnie zarysowany program PTP podano do publicznej wiadomości w formie prasowej publikacji w "Głosie Nauczycielskim” (1981, nr 46) zatytułowanej Uchwały w sprawach dla narodu najważniejszych. Podkreślono w niej znaczenie oświaty dla całokształtu życia społecznego wymagającego rekonstrukcji i naprawy, wypunktowano zadania wynikające $\mathrm{z}$ rozwojowych zaniedbań popełnionych wobec młodzieży, zwrócono się $\mathrm{z}$ apelem o udział $\mathrm{w}$ pracach oświatowych do wszystkich, którym przyszłość i dobro kraju leży na sercu. Był to komunikat dużego społecznego formatu.

Powołanie Towarzystwa w marcu 1981 roku było wyczynem! Za nim poszły intensywne prace podstawowe - ustanawianie oddziałów terenowych, gdzie organizowano zebrania naukowe, seminaria, konferencje, planowano i realizowano prace badawcze i wydawnicze, co robiono w nastroju prodemokratycznym, we współpracy z lokalnymi środowiskami nauczycielskimi. W skrócie można powiedzieć, że lata osiemdziesiąte stanowiły żywy okres rozruchu działalności Towarzystwa realizowanego wbrew trudnościom, jakie udawało się przezwyciężać dzięki poważnemu społecznemu zaangażowaniu ludzi PTP.

Pytając nadal o czas trudny, przechodzę do roku 1989, wyznaczającego przełom ustrojowy. W nową rzeczywistość weszliśmy $\mathrm{w}$ warunkach gwałtownej zmiany społecznej, spragnieni jej, a zarazem nieprzygotowani, gdyż nieposiadający wyraźnej, względnie jednolitej wizji przyszłości, odpowiednich mocy wykonawczych, a także obciążeni przeszłością zarówno w sferze materialnej, jak i mentalnej, co dotyczyło tak pedagogów, jak i tych, którzy mieliby stanowić ich „podopiecznych” (Kwieciński 1990).

Badania Jadwigi Koralewicz i Marka Ziółkowskiego obejmujące koniec lat osiemdziesiątych i okres późniejszy wykazały, że w mentalności Polaków tamtego czasu, scharakteryzowanej w wymiarach: indywidualizm - kolektywizm, podmiotowość - podporządkowanie, produktywność - receptywność, głęboko utrwalone były systemowe zaszłości (Koralewicz, Ziółkowski 2003). Dla pedagogów stanowiło to sygnał ogromu zadań stojących przed nową edukacją, ale też - pośrednio - źródło pytania, na ile my sami byliśmy gotowi do podjęcia tych prac.

Swiadomość ówczesnego stanu znalazła odbicie w mery torycznej formule i przewodnim haśle I Zjazdu PTP (1993), podczas którego postawiono kwestię tożsamości pedagogiki. Bardziej niż o uzyskanie jednolitego punktu widzenia na sprawę chodziło wówczas o zwrócenie się ku myślowemu przepracowaniu zagadnienia sensów, problematyki i metodologii dyscypliny naukowej, jaką uprawialiśmy, oraz naszej samowiedzy jako ludzi tej dyscypliny.

$\mathrm{W}$ aspekcie ustrojowym weszliśmy w makrostrukturę demokracji parlamentarnej, deklarowaliśmy też aktywność na rzecz demokratyzacji edukacji, co wymagało uwewnętrznienia odpowiednich zasad. W swoim czasie celnie zarysowała je Maria Ossowska, zbierając we wzór demokraty (Ossowska 1992), a później dopełniła 
Barbara Skarga w wykładzie o obywatelstwie wygłoszonym w Uniwersytecie Białostockim (Kraków 2007).

Jak jednak miały się te wzorce do nas samych - czy byliśmy demokratami, jak przedstawiał się nasz stosunek do obywatelstwa? Te sprawy, z którymi trzeba było się zmierzyć, także stanowiły jedną z trudności ówczesnego działania Towarzystwa.

W referacie wygłoszonym na I Zjeździe przez Przewodniczącego PTP, zatytułowanym Mimikra czy sternik? Dramat pedagogiki w sytuacji przesilenia formacyjnego, postawiono problem klarownie - szło o to, czy edukacja stanowi element przystosowania do aktualnych jakości, czy też jest czynnikiem emancypującym (Kwieciński 1993). W istocie chodziło o spór o edukację jako spór o zmianę społeczną - jak to celnie sformułował Lech Witkowski (Witkowski 2010).

Podczas pierwszego zjazdu zainicjowano poważny namysł i dyskusję nad tą tematyką uprawianą nadal, ze zmienną intensywnością, w latach dziewięćdziesiątych. Prowadzone dyskusje oddawały, a zarazem stymulowały tematyczne publikacje tamtego okresu; przypomnę tylko wybrane teksty opublikowane pod wymownymi tytułami: Andrei Folkierskiej Pytanie o pedagogikę (Folkierska 1990) oraz Roberta Kwaśnicy Ukryte założenia trzech krytyk. Przyczynek do samowiedzy pedagogii przejścia i pogranicza (Kwaśnica 1990).

W latach późniejszych namysł nad samowiedzą pedagogiczną wyraźnie słabł, być może dlatego, że mniej wyraziste były okoliczności mobilizacyjne. Działaliśmy bowiem w czasach już nie tak trudnych jak poprzednio, gdyż sprzyjających zarówno uprawianiu nauki, jak i prowadzeniu refleksji nad problematyką edukacyjną: mieliśmy coraz lepszy dostęp do narzędzi - lektur, kontaktów zagranicznych, były warunki poznawania i interpretacyjnego rozpoznawania dawniej „nieobecnych" dyskursów, prowadzenia działalności wydawniczej, korzystaliśmy ze swobody organizowania się, zwoływania konferencji naukowych, przeprowadzania ogólnopolskich zjazdów pedagogicznych, które odbywały się systematycznie co trzy lata.

Cały ten ruch owocował badaniami i wieloma świetnymi publikacjami, ale też i pytaniami o społeczny obieg myśli pedagogicznej i jakość ludzi jako realizatorów zmiany. Nie było w nim jednak dużego udziału tematyki poziomu akademickich pedagogów jako „łłumaczy” zachodzącej zmiany edukacyjno-społecznej, co byłoby potrzebne i ważne w świetle Baumanowskiego odróżnienia ich od „prawodawców” (Bauman 1998).

Do autoanalitycznego ukierunkowania wróciliśmy przy końcu lat dziewięćdziesiątych. Okazją do wymiany myśli na ten temat stał się V Zjazd Delegatów PTP, który odbył się w 1996 roku, nieomal w dziesięciolecie zmiany ustrojowej, i obradował nad tematem „Dorobek polskiej pedagogiki po 1989 roku”. Dorobek ten uznano za niemały, nawet imponujący (jak rzecz określił Tadeusz Lewowicki), co poparto przekonującymi danymi. Charakteryzował się on przechodzeniem od „[...] parcjalnych obrazów wiedzy do obrazu wypełnionego różnymi teoriami, koncepcjami i praktykami edukacyjnymi - o rozmaitych założeniach, kontekstach ideologicznych i społecznych, modelach realizacyjnych" (Lewowicki 1997: 11-13). To wówczas zarysowała się wielość tematów, metod i języków pedagogiki, które 
$\mathrm{z}$ biegiem czasu przekształciły się w nurty różnorodnych pedagogii (Jaworska-Witkowska, Kwieciński 2011).

Dobra jakość ówczesnych i późniejszych badań oraz licznych publikacji stanowi wskaźnik realizowania przez PTP tej linii zadań statutowych, które odnoszą się do udziału Towarzystwa w rozwoju naukowej wiedzy pedagogicznej. Stawiam tak sprawę, chociaż nie jest możliwe wyodrębnienie i oddzielenie działań Towarzystwa w tym zakresie od działań innych instytucji, takich jak: struktury akademickie, Komitet Nauk Pedagogicznych Polskiej Akademii Nauk, administracja szkolnictwa wyższego, zbieżnie ukierunkowanych na stymulowanie dynamiki naukowej. Pomimo takiego ograniczenia przyjmuję założenie o dodatniej roli działalności Towarzystwa dla naukowej aktywności środowiska pedagogicznego.

Pozytywnej, chociaż niekiedy także i krytycznej, ocenie ponad trzydziestoletniego dorobku naukowego pedagogów towarzyszą pojawiające się co jakiś czas pytania o funkcjonowanie owego dorobku w realnym obiegu społecznym.

Wyrażając zaniepokojenie o jakość pedagogicznego środowiska akademickiego jako nosiciela i propagatora tego dorobku, Kwieciński już w roku 1996 sformułował znaczące pytania: „Wszystkie patologie polskie odbijają się jak w lustrze w naszym środowisku, jak by nie było, akademickim. Któż ma zatem wychowywać to społeczeństwo? Kto ma kształcić jego wychowawców?” i wysunął postulat rzetelnego badawczego spenetrowania etosu akademickich instytucji pedagogicznych w całej Polsce, przy okazji „meliorując” samoświadomość zawodową pedagogów i w zakresie więzi wzajemnych (Kwieciński 1997: 8-9).

Odróżnianie stanu myśli pedagogicznej mierzonego dorobkiem naukowym od jakości jej społecznego obiegu powodowało skierowanie uwagi na to, że między teoretycznie wyeksponowanym, kluczowym w okresie przełomu, wyodrębnieniem „etatyzacji” i ,uspołecznienia” pedagogiki (Kwieciński 1996) pojawiło się nowe zjawisko dotyczące jej „prywatyzacji”.

W pierwotnym użyciu tego określenia nie chodziło o wieloetatowe zatrudnienie pedagogów w gwałtownie rozwijającym się szkolnictwie niepublicznym, tylko o mentalne ukierunkowanie ludzi edukacji budujących swoje pozycje z wynoszeniem dobra własnego, jako prywatnego, „domowego”, ale realizowanego też w instytucjach publicznych, ponad edukacyjne dobro wspólne. Społeczny sens tak rozumianej prywatności w swoim czasie przybliżyła Hannah Arendt: „Deprywacyjny charakter prywatności - pisała - polega na nieobecności innych; jeżeli chodzi o nich, człowiek wiodący życie czysto prywatne nie pojawia się, a zatem jest tak, jakby nie istniał. Cokolwiek robi, nie ma to znaczenia i następstw dla innych ludzi, a to, co jest istotne dla niego, ich nie obchodzi" (Arendt 2000: 45). W naszym przypadku szczególnie ważna była niska koncentracja, jakby nieobecność, zainteresowań ludzi wspólnotowym wymiarem problemów edukacyjnych, o jakich się wypowiadali.

$\mathrm{W}$ odpowiedzi na pytanie, czy wywodzące się z minionego systemu „upaństwowienie pedagogiki” zmieniało się w jej „uspołecznianie się”, podkreślano wagę rozwijania wielości odmian i języków myślenia o edukacji potraktowanych jako przejaw deetatyzacji, ale, obok tego, krytycznie zasygnalizowano nowe zjawisko 
„prywatyzacji” jako aktualnego stylu i sposobu uprawiania pedagogiki. Przejawiał się on w traktowaniu badań jako fragmentarycznych eksplikacji indywidualnych stanowisk $\mathrm{z}$ występowaniem na scenie pedagogicznej głosów zatomizowanych, oznaczających przywiązanie do własnych punktów widzenia bez zważania na całość kwestii edukacyjnej w jej makroskali, ze zminimalizowanym wysiłkiem słuchania innych, ustosunkowania się do nich przez czynienie wglądu ukierunkowanego zamiarem współdziałania odnoszącego się do społeczno-edukacyjnej realności i jej całościowego, emancypacyjnego przekształcania (Rutkowiak 1997: 20-21).

To w tamtym okresie ukształtował się na konferencjach charakterystyczny sposób komunikowania polegający na wygłaszaniu kwestii niejako obok siebie, kiedy każdy referent przedstawiał własne sfragmentaryzowane tezy, nawet nie zawsze w pełni odpowiadające tematyce danej konferencji, a na dyskusję nie wystarczało czasu, a - być może - także wewnętrznej motywacji. Oznaczało to „indywidualizm badawczy” (Cierzniewska 2011: 353), nieodpowiadający zasadzie równowagi mówienia/słuchania charakterystycznej dla stosunków demokratycznych, nie sprzyjało skupianiu wysiłków i ukierunkowaniu pedagogiki ku budowaniu edukacji pojmowanej jako „ruch i dzieło społeczne”, jak pionierskim językiem określił Kwieciński edukację demokratyczną i humanistyczną (Kwieciński 1982.)

Właśnie wtedy na pewnym spotkaniu Towarzystwa usłyszałam sformułowanie „między nami - prywaciarzami” potraktowane jako żart, ale żart, w którym zwerbalizowano egoizowanie się zachowań i układanie relacji ze współuczestnikami wydarzeń jako relacji typu separatystycznego, co sprzyjało redukowaniu namysłu nad edukacyjną całością jako dobrem wspólnym.

Zachowania uczestników ówczesnych spotkań naukowych organizowanych przez Towarzystwo można skomentować przez pryzmat praktyki wolności negatywnej, odbieranej jako brak ograniczeń. Prawdopodobnie zanik dawnych systemowych barier wobec podejmowania określonych tematów i sposobów uprawiania badań z osadzaniem ich w paradygmacie pozytywistycznym uznawanym za wzorcowy wywołał erupcję nastroju wolności, jak i zaowocował wielogłosem, który jednak nie organizował się $w$ całość myślową typu paradygmatycznego w takim stopniu, jaki sprzyjałby rozwojowi edukacji uspołecznionej, budowanej ku dobru wspólnemu. Jaka nie byłaby przyczyna przedstawionego stanu rzeczy, brak takiej świadomości stanowił słabą stronę naszych ówczesnych poczynań.

Zaistniałą sytuację można też teoretycznie osadzić w polu wyższej ogólności z odniesieniem do narysowanej przez Rolanda G. Paulstona konceptualnej mapy paradygmatów - ortodoksji, heterodoksji i heterogeniczności, przedstawionej przez Kwiecinskiego na I Zjeździe PTP, a następnie eksploatowanej poznawczo w analizach stanu polskiej pedagogiki (Hejnicka-Bezwińska 1997, 2011).

Jakkolwiek nie zinterpretujemy nastrojów, które wówczas bodaj słabo sami rozpoznawaliśmy, trzeba podkreślić, że upajaniu się indywidualnymi znaczeniami odkryć bądź paraodkryć każdego edukatora, dokonywanych jakby z własnej tylko potrzeby poznawczej, nie towarzyszyło wyraźne łączenie wysiłków uspołecznionych 
pedagogów ukierunkowanych troską o budowanie edukacji jako istotnego dzieła o znaczeniu publiczno-wspólnotowym.

W tym miejscu nawiążę do idei odpowiedzialności uczonych opracowanej teoretycznie, ale też i osadzanej instytucjonalnie, co objawia się we wpisaniu tej kwestii do statutów niektórych polskich towarzystw naukowych . Otóż wydaje się, że w pewnym momencie osłabiła się bądź umknęła nam sprawa współodpowiedzialności PTP za kwestię oświaty, chociaż publiczne bardziej zdecydowane jej nagłaśnianie byłoby szczególnie znaczące w sytuacjach realizowania fundamentalnych przekształceń edukacyjnych: przygotowania i wprowadzania reformy systemu oświatowego (1999), tworzenia nowych podstaw programowych, wprowadzania metod zewnętrznego, wystandaryzowanego oceniania jako faktycznego narzędzia selekcji szkolnych, zmieniania zasad kształcenia i zawodowego doskonalenia nauczycieli, reformowania szkolnictwa wyższego, osadzania dzieci młodszych w instytucjach oświatowych, jakości uzyskiwanych wyników kształcenia, co niektórzy, dostrzegający w owych wynikach wskaźniki mentalnego stanu społeczeństwa, określają dziś jako klęskę edukacyjną.

Ostatnio sprawy dotyczą prezentowanych w sieci zapowiedzi wprowadzania od roku 2017 przyśpieszonych „szkolnych rewolucji” ze zmianami w strukturze ustroju szkolnego, zmianami w podstawach nauczania historii, koncepcjach szkolnictwa zawodowego, z przekształcaniem „zawódowek” w „branżówki”, zmianami zasad wyboru dyrektorów szkół, pracy wychowawców klasowych, a także z osłabianiem roli samorządów w zarządzaniu oświatą (https:men.gov.pl).

Po pierwszej, charakterystycznej dla początku lat dziewięćdziesiątych, spontanicznej i jeszcze jakby „niewinnej” fali prywatyzowania się pedagogiki utrzymanej w tonacji zabiegów o indywidualne pozycje, mające bodaj w swoim podłożu psychospołeczne właściwości zachowań ludzi uprawiających izolacjonizm w warunkach gwałtownej demokratyzacji życia, nadeszła jej fala druga, znacznie bardziej zaawansowana.

Postrzegam ją jako już ponadindywidualne, gdyż systemowo zinstrumentalizowane, sprowadzanie aktywności edukatorów do wyrachowanych zachowań ukierunkowanych na budowanie własnych karier metodami wzorowanymi na schematach rynkowych, zharmonizowanych $\mathrm{z}$ mechanizmami systemu. Jest to prywatyzacja w większej skali, ugruntowana instytucjonalnie i usankcjonowana prawnie odpowiednim układem procedur, z presją na sukces widziany jako rodzaj zysku, osadzona merytorycznie w neoliberalnej zmianie kulturowej.

Opisy mechanizmów na rzecz kształtowania odpowiednich ludzkich postaw i zachowań można odnaleźć w treściach strategicznych dokumentów (niekiedy projektów) o kierunkach rozwoju i reformowania szkolnictwa wyższego w obszarze naukowym oraz zarządzania szkolnictwem wyższym, a także w taktycznej, obudowanej licznymi dokumentami akcji biurokratyzowania dydaktyki z dehumanizowaniem i wyzuciem naszej pracy z indywidualnej odpowiedzialności „regulowanej” wprowadzaniem detalicznej kontroli jako narzędzia nadzoru. Przykładowo 
w naczelnym dokumencie wyznaczającym jakość kształcenia charakteryzuje się ją jako zgodność ze standardami oraz użyteczność dla nabywcy (Hornowska 2003).

Co ważniejsze, biurokratyzowaniu szkolnictwa, bodaj najbardziej intensywnemu na poziomie wyższym, towarzyszy naturalizowanie i interioryzowanie rynkowego porządku przez niemałą część samych pracowników naukowych, których pasją staje się uzyskiwanie biegłości w posługiwaniu się procedurami, czemu nierzadko towarzyszy osłabianie zaangażowania w meritum uprawianej tematyki naukowej. Wydają się oni godzić z zamianą swojej pozycji uczonych na pozycję pozbawionej zaufania „wspólnoty audytowanych” (Kruszelnicki 2011: 179), chociaż - zarazem - gorzka tonacja codziennych wypowiedzi ludzi nauki świadczy o tym, że odchodzenie od akademickiego i przyjmowanie menadżerskiego stylu zarządzania uczelniami wywołuje głębokie dyssatysfakcje. Całość tej sytuacji świadczy o wewnętrznym rozdarciu tożsamości akademików.

Szerzej rzecz ujmując, powiedzmy, że kierunek aktualnych zmian sprzyja zamienianiu ruchu i obiegu tradycyjnie zakorzenionej w szkołach wyższych żywej myśli badawczo-dydaktycznej, przesyconej twórczymi wysiłkami i wysokim wartościowaniem wiedzy autotelicznej oraz interakcyjno-humanistycznych działań podmiotów edukacyjnych - ludzi szkolnictwa wyższego różnych dziedzin i poziomów oraz ich studentów, kształtowanych jako ludzie-obywatele, w działania coraz bardziej sformalizowane, zalgorytmizowane, wystandaryzowane, poddawane zasadzie kwantyfikacji sprzyjającej statystycznej obróbce porównawczej umożliwiającej pozycjonowanie (a jest to termin z zakresu marketingu) przez zestawianie aktywności ludzi z urzędowymi formułami oraz motywującej rywalizacyjne nastawienia pracowników szkolnictwa. Wiąże się to też ze zmianami wewnątrz instytucji akademickich i ich orientacją na "produkt naukowy i edukacyjny” (Cierzniewska 2011: 353) proweniencji tradycyjnie fabrycznej (Czerepaniak-Walczak 2013). Oznacza ukierunkowanie wysiłków akademików na opanowywanie zasad regulacyjnych, a w sferze naukowej na uprawianie piśmiennictwa awansowego ku budowaniu sukcesów własnych, co nadal określam mianem prywatyzacji. Zaznaczę raz jeszcze, że jest to jednak prywatyzacja inna niż ta z pierwszej fali, gdyż nie tyle dotycząca treści zainteresowań i wyników badań, uznawanych przez poszczególnych badaczy za znaczące na tyle, że prezentacyjnie zasługujące na eksponowanie przed innymi, ile promująca badania własne jako narzędzie zdobywania miejsca w układzie rywalizacyjnym wydajnych naukowców jako ludzi gry rynkowej dominującego systemu.

Samo szkolnictwo wyższe, jako instytucja ramowa dla ich działań, jest tutaj traktowane jako usługowe przedsiębiorstwo ukierunkowane na „produkcję wiedzy" (Kwiek 2015a: 35), będącej - w istocie - paliwem dla konkurencyjnego globalnego rozwoju gospodarczego oraz dla fabrycznego produkowania dyplomów absolwentów szkół wyższych, stanowiących ludzki kapitał wydajnej, szeroko rozumianej pracy produkcyjnej.

Idąc tą drogą, ukierunkowaną przez „poczynania reformatorskie”, jak się je określa, zaproponowano dzielenie uczelni na naukowe - „okręty flagowe” - oraz 
uczelnie dydaktyczne - przygotowujące studentów do standardowych prac robotników umysłowych i politycznie zagospodarowujące społeczny czas młodych ludzi. Jest to koncepcja przeciwstawna wobec Humboldtowskiej idei uniwersytetu łączącego uprawianie nauki i dydaktyki, spinającego gałęzi wiedzy, budującego poznawcze relacje profesorów i studentów, gdyż jednostronnie wynosi się w niej pragmatyczne funkcje kształcenia $z$ separowaniem od funkcji społecznego oświecania i czynienia lepszym życia ogółu, nieograniczanego do wydajności i efektywności finansowo-produkcyjnej. Podstawą odpowiedniego klasyfikowania akademików mają być wyniki naukowe uzyskiwane w ramach sformalizowanego, silnie konkurencyjnego, międzynarodowego układu grantowo-punktowo-rangowego, z immanentnie weń wpisanym współzawodnictwem bazującym na prywatyzacyjnym ukierunkowaniu podmiotów zabiegających o własną pozycję w wyścigu.

W tej sytuacji intrygująca staje się sprawa samowiedzy akademików zarówno tych „zdydaktyzowanych”, jak i „prawdziwych naukowców”, ukierunkowanych na produkowanie wiedzy na najwyższym międzynarodowym poziomie. Rzecz dotyczy świadomej orientacji tych pierwszych $w$ fakcie degradacji ich aktywności akademicko-dydaktycznej, wywołanej rzeczywistym, organizacyjnym i finansowym separowaniem od uprawiania nauki, co obniży poziom kształcenia na poziomie wyższym, a w następstwie - umniejszy mentalny stan społeczeństwa, oraz orientacji tych drugich, służących swoją energią i talentami rywalizacji współczesnej korporacyjnej gospodarki światowej z terrorem rozwoju gospodarczego, działających w imię problematycznego „postępu”, co - pośrednio - oznacza współudział akademików w wytwarzaniu drastycznego rozwarstwienia społecznego, uznawanego obecnie za największy problem współczesności (Piketty 2015). Problem ten gwałtownie narasta, przybierając formę nakładających się kryzysów: cywilizacyjnego, politycznego, ekonomicznego, instytucjonalnego, objawem których jest ostatnio dramatyczny ruch migracyjny. Wymagają one zastosowania zrównoważonych rozwiązań globalnych, ale - póki co - rozwiązań takich nie są w stanie wykreować nawet najlepsi „producenci wiedzy”. Czy jesteśmy więc na dobrej drodze? Czy nie wykonujemy ruchów autodestrukcyjnych?

Namysł nad metapoziomem naukowego wyścigu o zabarwieniu prywatyzacyjno-rynkowym odsłania aktualną jakość nienowej kwestii społecznej odpowiedzialności i etycznych zachowań ludzi nauki. Czy stanowią one tematy autorefleksji uczonych w dzisiejszych czasach trudnych, chociaż trudnych inaczej niż dawniej? Czy towarzystwa naukowe inicjują i podtrzymują dyskusje o współczesnej pozycji nauki i samowiedzy uczonych? Czy ich głos zaznacza się i daje do myślenia w sferze publicznej? Jak w tej sprawie prezentuje się aktywność Polskiego Towarzystwa Pedagogicznego?

Po przedstawieniu wątku zmian zachodzących obecnie w szkolnictwie wyższym wracam do kwestii osadzenia zjawiska drugiej fali prywatyzacji pedagogiki w określonym kontekście społeczno-kulturowym. 
Kontekst taki stanowi współczesny, rozwijający się w skali globalnej, stan neoliberalizacji wszystkich dziedzin życia, dotyczący także uprawiania i aplikowania nauki. Scharakteryzowany wielostronnie w literaturze, określany mianem kapitalizmu finansowego, stan ten znaczy się przede wszystkim radykalnym urynkowieniem instytucji, działań, myśli i wartości ludzkich ukierunkowanych na maksymalizowanie realnych i możliwych zysków oraz - stanowiącymi ich konsekwencje - drastycznymi nierównościami dystrybucji owocującymi zróżnicowaniami społecznymi z nierównowagą nadmiaru/niedoboru wszelkich dóbr, obejmującego także i sferę edukacji.

$\mathrm{Na}$ te nierówności, a dokładniej na jeden ich aspekt - na braki dostępu i niską skolaryzację społeczeństwa polskiego w minionych dekadach, pedagodzy zareagowali wieloetatowym zatrudnieniem $\mathrm{w}$ gwałtownie rozwijającym się niepublicznym szkolnictwie wyższym. Zaowocowało to osłabieniem aktywności badawczej szczególnie wyraźnie występującej w dyscyplinach „miękkich”, do których zalicza się pedagogikę, co przebadano, udokumentowano i zinterpretowano przez aplikację teorii instytucjonalizacji, deinstytucjonalizacji i reinstytucjonalizacji badawczej misji polskich uczelni (Kwiek 2015b).

Skierowanie aktywności na działalność organizacyjno-dydaktyczną, z osłabianiem naukowej, a dokładniej - z jej koncentracją w rękach części środowiska, pedagodzy nierzadko racjonalizują wysuwaniem na czoło szczytnej idei udostępniania oświaty, tradycyjnie wpisującej się w ich etos. Dawne romantyczne zawołania, wzmocnione współczesnymi wynikami badań dokumentujących nierówności edukacyjne i ich negatywne skutki dla rozwoju jednostek i społeczeństw (Potulicka 2012a, 2012b), stanowiły niejako uzasadnienie nasilonej dydaktyzacji aktywności pedagogów. Zastanawiając się, w szerszym planie, nad bezradnością czy zaniechaniem, usprawiedliwieniem czy winą pedagogów w czasach potrzeby (dodam, że idzie zarówno o potrzeby społeczne, jak i indywidualne, prywatne), Tadeusz Pilch wysunął przekonującą tezę, że występowanie postawy wycofania i oportunizmu wykształciło poczucie bezradności nauki i uczonych wobec rzeczywistości społecznej, jakie naznaczyło na długie lata środowisko intelektualne pedagogiki i ,[...] wywołuje alergiczne reakcje na apele o obecność w życiu publicznym" (Pilch 2004: 67).

Omawiając dalej zjawisko prywatyzacji pedagogiki, podkreślmy, że łączy się ona $z$ występowaniem podskórnych, dwuznacznych nacisków, nieprostych w warstwie interpretacji, rodzących pulsujące napięcia i wahania odnośnie do tego, czy edukacja i pedagodzy jako jej ludzie są rzeczywiście uwikłani w neoliberalną matnię, czy dotyczy ona polskiej sytuacji edukacyjnej, czy jest tylko nieszkodliwym objawem globalnego postępu i rozwojowej normy współczesności.

Stanowi to kontekst stanu, kiedy z planu zewnętrznego, gdy dotyczyła ona zderzenia zamierzeń i chęci badawczych pedagogów aktywnych w niełatwych warunkach systemowych i życiowych, przeszła ona w plan wewnętrzny, dotyczący mentalnego nastawienia wobec obecnej kulturowej rzeczywistości, w którą edukacja jest uwikłana i która wywołuje jej paradoksy (Potulicka, Rutkowiak 2012; Boryczko 2015). 
Zastanawiając się nad możliwością myślowego objęcia tej sytuacji, można rzecz całą sprowadzić do kwestii kolizji etosu i interesu, która stawia nas na rozdrożu koncentrowania prac naukowych na zagadnieniach prorozwojowej edukacji pojmowanej i uprawianej, na przekór realiom rzeczywistości, nadal jako „ruch i dzieło społeczne", albo stosowania zachowań imitacyjnych, pozornych (Dudzikowa, Knasiecka-Falbierska 2013), ukierunkowanych na sukcesy własne, z cynizmem w tle. Oskar Szwabowski ujął zagadnienie radykalnie, zwracając uwagę, że sprzyja to stosowaniu dwuznacznych rozgrywek: „W neoliberalnym zarządzaniu, ciało akademickie staje się albo ciałem poddanym, tresowanym, szkolonym, aby przestać być leniwym, stać się w pełni elastycznym, mobilnym, konkurencyjnym, albo staje się ciałem taktycznym, podejmującym akty oporu, sabotażu, oszustw, łamania zasad gry" (Szwabowski 2014: 216).

Postawienie sprawy kolizji etosu i interesu zawiera w sobie pewną dozę uproszczeń, wiążących się z wyodrębnianiem możliwych znaczeniowych odcieni relacji tych fenomenów - jak idea „etycznego interesu”, ale pomimo to może być użyteczne jako zabieg wspomagający uprawianie środowiskowego namysłu nad sobą, z przechodzeniem od akceptacji i uległości wobec zewnętrznych instrumentalnych nacisków i oddziaływań, kiedy uznajemy, że nie sposób uniknąć wymagań sytuacji, do myślowego przepracowania tej problematyki, ukierunkowanego na uruchamianie możliwej aktywności typu oporowego i odporowego, uprawianej wbrew warunkom i czasom trudnym w ich obecnej jakości.

Jednakże samo postawienie sprawy nie jest wystarczające, ponieważ liczą się realne zachowania ludzi, a te wiążą się ze stanem ich samowiedzy i rozpoznawaniem kulturowej jakości czasów, w jakich działają; obecnie jest to czas zdublowany, a wiec niełatwy do rozszyfrowywania. Z jednej strony sprzyja on nam przez to, że eksponuje, oferuje, wręcz narzuca obfitość ofert, także edukacyjnych, z drugiej zaś strony stosuje kamuflowanie negatywnych skutków owego dostępu.

Kłopoty ze świadomym byciem w układzie neoliberalnym wynikają z nieodróżniania, także przez część akademików, jakości tego systemu (doktryny politycznej, światopoglądu, teorii makroekonomicznej, ideologii) od idei i praktyk liberalizmu. Nieporozumienia w zakresie terminologicznym, które nie ograniczają się tylko do tych dwóch pojęć, mają wyraziste konsekwencje, wręcz, jak uzasadnia Andrzej Walicki, wywierają „[...] deformujący wpływ na świadomość społeczną a nawet na kształt tworzonego przez nas ustroju" (Walicki 2013: IX).

Trudności rozszyfrowania współczesnej dominacji neoliberalizmu oraz uwarunkowań świadomościowego ogarniania jego niezwykłej żywotności naświetlił niedawno Colin Crouch. Jest on zdania, że w centrum zagadki leży rozbieżność między neoliberalizmem faktycznie istniejącym a jego sterylną ideologiczną wersją. Faktyczność polega na dominacji potężnych korporacji w życiu publicznym, podczas gdy ideologiczną wersję neoliberalizmu buduje polityczny konflikt między państwem a rynkiem (Crouch 2015: 83). Ta sprawa wypada dyskusyjnie w wymianie myśli pedagogów, kiedy część z nich postrzega państwo jako siłę potencjalnej 
poprawy stanu edukacji prowadzonej przez ograniczanie prywatyzacji, a inni oceniają państwo jako układ destrukcyjny dla edukacji. Zagadnienie to wyraziście prezentuje w swoich pracach Bogusław Śliwerski (2015).

Możliwość innej interpretacji zagadnienia wyprowadzam z inspiracji książką Andrzeja Ledera o prześnionych rewolucjach. Dwie rewolucje, które autor wziął na warsztat historyczno-psychoanalityczny z nachyleniem Lacanowskim, dotyczą konsekwencji zagłady Żydów jako polskiego mieszczaństwa dokonanej podczas drugiej wojny światowej oraz zagłady polskiego ziemiaństwa po 1945 roku. Wydarzenia te, znaczące dla kształtowania się tożsamości Polaków, były nam narzucone z zewnątrz, przeprowadzone przez obce siły przy nieświadomym, pasywnym, niejako uśpionym, bezwiednym uczestnictwie „obiektów rewolucji”, których dotyczyły. Trzeba pamiętać, że było to społeczeństwo źle wykształcone, zachowujące w swojej mentalności pozostałości gospodarki folwarcznej typu niewolniczego, uprawianej w Polsce do połowy XIX wieku w formule niejako przedłużonego średniowiecza (Sowa 2011; Raport „Polska 2050” 2011). Leder przeprowadził na ten temat ćwiczenia z logiki historycznej, ja natomiast sugeruję zastosowanie analogii i potraktowanie wprowadzenia do Polski neoliberalnej zmiany kulturowej jako jeszcze jednej prześnionej rewolucji, która nas dotknęła.

Ta trzecia, tak samo jak poprzednie rewolucje: mieszczańska i ziemiańsko-chłopska, spadła na nas z zewnątrz, w okolicznościach szoku politycznej i gospodarczej zmiany systemowej końca lat osiemdziesiątych. Ponieważ nie była i ciągle nie jest myślowo przez nas przepracowana, nie doprowadza do stanu uzyskania wyrazistej, określonej tożsamości (tutaj interesuje nas tożsamość pedagoga i pytanie, na ile skonsumował on poznawczo zachodzące przemiany edukacyjno-neoliberalne), co powoduje, jak to szerzej naświetla Leder, że współczesny członek społeczeństwa, któremu brakuje adekwatnej tożsamości, „[...] pasywnie doświadcza emancypacji, gdyż jest ona nieobecna w jego myśleniu [...], unika wejścia w życie publiczne jako świadomy siebie podmiot polityczny" (Leder 2014: 8). Otóż jestem zdania, że w analogiczny sposób można uzasadniać umiarkowany udział pedagogów w dzisiejszym życiu publicznym.

Wracając do doświadczeń naszego funkcjonowania w Polskim Towarzystwie Pedagogicznym, powiedzmy, że zryw ku przebudzeniu (jeśli użyjemy języka Ledera) w formie zorganizowanego, uzewnętrznionego, wspólnotowego, tożsamościowo klarownego ruchu wykonaliśmy bodaj jeden raz w ciągu tych 35 lat, a rzecz dotyczyła wydarzeń na VI lubelskim Zjeździe PTP w roku 2007. Najpierw w toku dyskusji Komitetu Programowego sformułowano jego temat, który brzmiał „Edukacja - moralność - sfera publiczna”. I chociaż nie udało się wprowadzić do tytułu Zjazdu pojęcia „etyczność" zamiast „moralność", co byłoby zgodne z pierwotną intencją, to udało się postawić problem osadzenia i jakości realnego funkcjonowania edukacji w sferze publicznej, jako stanu rozmijania się i z deklaracjami, i potrzebami społecznymi. 
Jednakże samo sformułowanie mobilizacyjnego hasła nie było wystarczające, gdyż należało zaprojektować rozwiązania robocze. Duży udział w tej pracy mieli członkowie PTP z Gdańskiego Oddziału Towarzystwa. Pamiętam zebranie, na którym uznaliśmy, że należy w sposób zorganizowany nazwać na Zjeździe kwestie nabrzmiałe dla edukacji w aspekcie oświatowo-etycznym. Działania były błyskawiczne, gdyż na tymże zebraniu zgłosiliśmy dostrzegane przez nas "gorące" problemy, wokół których spontanicznie ukonstytuowały się małe grupy robocze. W ciągu kilku dni opracowały one podjęte tematy, a dokument w całości został zredagowany przez Astrid Męczkowską-Christiansen i Piotra Zamojskiego.

Był on zatytułowany Stanowisko uczestników VI Ogólnopolskiego Zjazdu Pedagogicznego Polskiego Towarzystwa Pedagogicznego w sprawie stanu i perspektyw rozwoju edukacji w Polsce i dotyczył następujących zagadnień:

- zawłaszczania oświaty przez doraźne interesy polityczne;

- zagrożenia dla nabywania kompetencji intelektualnych i obywatelskich przez treści i formy szkolnego kształcenia;

- konsekwencji reform edukacji (1999) jako przeciwstawnych jej pierwotnym założeniom;

- odtwarzania nierówności społecznych przez szkołę;

- nasilania oświatowych mechanizmów selekcyjnych wytwarzających mit powszechności wykształcenia Polaków;

- załamywania się etycznej odpowiedzialności wychowawczej jako wyniku biurokratyzacji zarządzania;

- zaniku publicznej debaty nad edukacją.

Przytaczam śródtytuły dokumentu, żeby zwrócić uwagę na język, jaki wówczas wypracowano, a był to język całościującego ujęcia i rzeczowego uzasadnienia tematu z wyeksponowaniem jego aktualnej wagi wspólnotowej, przesyconej troską o poprawianie jakości edukacji. Zaznaczyła się w nim merytoryczna wyrazistość referowania spraw, bez sloganowego kamuflażu i nadspecjalistycznego słownictwa, co czyniło treści klarownymi i dostępnymi dla każdego, kto działał w obszarze edukacji - od nauczyciela po pracownika akademickiego i oświatowego decydenta, ponieważ były one ukierunkowane na publiczne zaprezentowanie dokumentu z nadzieją na społeczny odzew. Demaskatorsko wskazano w nim na sedno związków między stanem edukacji a jakością życia społecznego oraz brakiem koherencji owych relacji wobec ustrojowych założeń demokracji. Był to więc dokument nazywający sprawy o wadze podstawowej dla edukacji jako niezbędnego nam dzieła społecznego, ale dzieła faktycznie nierealizowanego.

Błyskawiczne tempo przeprowadzonych wówczas prac i doskonałe współdziałanie ludzi świadczyły o napięciu, które wzbudzała poruszona tematyka, a także o występowaniu silnej wewnętrznej motywacji oraz gotowości do postawienia zagadnienia na forum publicznym.

Losy dokumentu były takie, że został on przyjęty przez większość uczestników jako stanowisko Zjazdu, ponieważ w głosowaniu tajnym „za” opowiedziało się 
68\% uczestników. Oznaczało to jednak, że trzecia część uczestników Zjazdu nie aprobowała podstawowych tez o złym stanie oświaty i potrzebie poprawy zreferowanych rzeczowo i z umiarkowanym krytycyzmem. Ten wynik, zastanawiający po dziś dzień, był swojego rodzaju wskaźnikiem stanu „pedagogicznego ducha” akademickiego środowiska edukatorów. Ważne dla sprawy pytania postawiła już później Ewa Rodziewicz, komentując, że „[... [32\% uczestników VI Zjazdu odmówiło?, wstrzymało się od głosu?, zaniedbało fakt zajęcia stanowiska?, nie poparło stanowiska Zjazdu. Ta sytuacja daje do myślenia i rodzi dalsze pytania o to, jakie są orientacje pedagogiczne, ukryte i jawne programy myślenia, stanowiska pedagogów wobec kondycji pedagogiki współczesnej, stanu oświaty, uruchomionego kierunku dyskursu w ramach PTP w Polsce/w Gdańsku?” (Rodziewicz 2008: 56). Pytania te nadal pozostają otwarte.

Próby opublikowania dokumentu zjazdowego w masowych środkach przekazu, a tej pracy podjął się Dariusz Kubinowski - Przewodniczący Komitetu Organizacyjnego, nie powiodły się; nie było ani druku, ani żadnego sygnału zwrotnego w tej sprawie, choć tekst jest dostępny w tomie materiałów zjazdowych (Rutkowiak, Kubinowski, Nowak 2007: 19-24).

Całą tę sprawę można $\mathrm{z}$ jednej strony zinterpretować negatywnie jako wyraz marginalizowania na polu publicznym głosu członków towarzystwa naukowego o stanie oświaty, a także ograniczania społecznego znaczenia jej samej. Ale można też potraktować niepowodzenie PTP jako skutek nieupolitycznienia Towarzystwa (przy odróżnianiu upolitycznienia od polityczności), oznaczającego brak ideologicznego uzależnienia, jakie mogłoby wspomagać opublikowanie zjazdowego dokumentu. Czy nieskuteczność próby postawienia tematyki edukacyjnej w obszarze sfery publicznej stanowiła świadectwo patologii samej tej przestrzeni, czy wynikała z niezależności Towarzystwa, czy ze zbyt słabego zaangażowania jego członków?

Przypomniane zjazdowe wydarzenia $\mathrm{z}$ roku 2007 wywołują temat krytycznego uprawiania pedagogiki. Pedagodzy publikują dużo ważkich tekstów krytycznych, odbywają się też konferencje tematyczne i w tych przedsięwzięciach aktywnie uczestniczą członkowie PTP. Ta aktywność może podważać tezę o neoliberalnym, jako kulturowo-tożsamościowym, uśpieniu pedagogów, ale może oznaczać artykułowanie ruchu myślowego, tyle że dotyczącego zagadnień fragmentarycznych albo formułowanych w hermetycznym języku profesjonalistów, co skutkuje brakiem przenikania tematyki edukacyjnej do szerszej publiczności. Powoduje to „nieobecność pedagogiki”, „[... jej marginalne miejsca w uniwersytecie i słabą, niemą pozycję w przestrzeni publicznej” (Kopciewicz 2012: 36). Stan ten dobrze oddaje opinia, jaką usłyszałam w kuluarach konferencyjnych: „Pedagogika krytyczna ma się dobrze, ale jest martwa".

Nawiązuje się w niej do luki między treściami analiz merytorycznych, wskazujących na niedociągnięcia edukacyjne, a niską jakością praktyki oświatowej, co oznacza, że ostrzeżenia nie są przekładane na działania, lub, być może, są niewłaściwie 
formułowane, co wynika $\mathrm{z}$ kolei z braku naszego troskliwego i zarazem czytelnego zainteresowania całością edukacyjną albo oznacza takie biurokratyczno-systemowe obwarowanie owej praktyki, że trudno o dyskursywny dostęp do niej. Wiąże się to z paratechnicznym ukierunkowaniem nauczycieli i odsuwaniem profesjonalnych pedagogów od udziału w koncepcyjnych pracach ciał oświatowych, a przejawia się w zerwaniu, dawniej żywych, roboczych kontaktów między nauczycielami, rodzicami uczniów i akademikami.

Obecne instrumentalne traktowanie nauczycieli jako pozbawionych zaufania techników edukacji, nie zawsze świadomościowo rozszyfrowujących własną pozycję i sytuację, w jakiej działają, powoduje, że szukają oni bardziej instrukcji niż refleksji edukacyjnej, przedkładają więc kontakty z pragmatycznymi interpretatorami aktualnych przepisów albo dystrybutorami ściąg metodycznych nad kontakty z myślicielami ogólnymi, operującymi językiem „nieprzydatnej abstrakcji”, a tak określa się akademickich pedagogów w ramach pejoratywnej etykiety.

Zarazem jednak nauczyciele są głęboko nieusatysfakcjonowani obecnym własnym statusem zawodowym, a ich stan można określić jako dramatyczny, taki, w którym narzucane im rozwiązania zderzają się z zasadami etosu zawodowego, ciągle jeszcze wśród nich żywego (Klus-Stańska 2006; Rutkowiak 2012). Jeżeli jest tak właśnie, to można mieć nadzieję, że wciąż tli się potencjał naszych, niegdyś owocnych, wzajemnych kontaktów.

Podjęty wątek zamykam konstatacją, że słaba żywotność pedagogiki krytycznej wynika z jej zamknięcia; jest to częściowo zamknięcie językowe, ale również i merytoryczne, kiedy koncentrujemy się na sprawach fragmentarycznych bez dostrzegania związków z całością społeczną, w jakiej żyjemy, albo takich, w których krytycy stanowią zarazem nienazwany obiekt krytyki, co nie jest przekonujące dla odbiorców. Zilustruję to przykładem konstatacji o obniżaniu poziomu kształcenia w masowych uczelniach wyższych, gdzie kilkuetatową pracę dydaktyczną, nie zawsze najwyższej jakości, wykonują ci sami ludzie, którzy zarazem bywają autorami krytycznych tekstów dotyczących negatywnych aspektów polskiego boomu edukacyjnego. Takie praktyki osłabiają wymowę uprawiania krytyki.

Argument przekonujący wobec omawianej sprawy wysunął Witkowski, który nie tylko opowiedział się za uprawianiem pedagogiki krytycznej, ale też sformułował wyrazistą tezę: „Jeśli pedagogika jest na serio (czyli jest pedagogiką tout court) - to jest krytyczna" (Witkowski 2012: 19) i potraktował ów krytycyzm jako postulat metateoretyczny, co oznacza, że pedagogika nie może być tylko demaskatorska, czyli „zrywająca maskę”, ale powinna być także „alarmistyczna”, co oznacza diagnozę, że maski zdjąć się nie da, gdyż ma miejsce zagrożenie zasadnicze (Witkowski 2012: 26).

Czy Polskie Towarzystwo Pedagogiczne stanowi forum nazywania zasadniczych, alarmistycznych zagrożeń edukacyjnych, czy skupia się tylko na okazjonalnych i fragmentarycznych prezentacjach spraw wagi średniej? Takie pytania warto sobie zadać w roku jubileuszowym. 
Przedstawiony przegląd wybranych prac i wydarzeń daje powód do twierdzenia, że jako członkowie Polskiego Towarzystwa Pedagogicznego nie mamy podstaw, aby w pełni dodatnio podsumować 35-lecie naszej działalności. Czas ten przyniósł, obok licznych osiągnięć, dotyczących przede wszystkim udziału w rozwoju nauk pedagogicznych, co odpowiada części statutowych zadań Towarzystwa, także i braki, które można związać z drugą częścią owych zadań dotyczących propagowania wiedzy o edukacji i reprezentowania jej problemów i interesów wobec władz i opinii publicznej, ukierunkowanego na budowanie edukacji na miarę czasu świata i potrzeb ludzi.

Nie idzie przy tym o elementarną popularyzację wiedzy o wychowaniu, lecz szerzej - o życie owej wiedzy w umysłach ludzkich, czyli o jej społeczny obieg, wspierany czynną troską Towarzystwa o społeczno-obywatelską edukacyjną świadomość nauczycieli, rodziców, uczniów, decydentów oświatowych, polityków, ludzi środków przekazu, którzy w większości funkcjonują obecnie na poziomie opinii potocznych, intuicyjnych, wąsko empirycznych, sensacyjnych, amatorskich, przypadkowych, imitacyjnych, interesownych, upolitycznionych, pozbawionych orientacji w genezie, sensach, wadze oraz powadze planowanych i stosowanych rozwiązań oświatowych (Dobrołowicz 2013).

Działania projektowane i realizowane $\mathrm{w}$ oparciu o takie zasoby przynoszą szkody społeczne wynikające $\mathrm{z}$ braku rozpoznawania złożoności zjawisk, ich kontekstowego osadzenia, nieprowadzenia analiz stanu edukacji oraz stronienia od uruchamiania perspektywicznej społecznej wyobraźni jako drogi tworzenia społecznych imaginariów edukacyjnych. W opozycji do tego stanu trzeba mieć nadzieję, że upublicznianie wiedzy o edukacji może przyczyniać się do intensyfikacji przemyśleń, racjonalizowania intencji i wykonywanych działań, pogłębiania namysłów i ograniczania szkód przez otwieranie szans dla pomysłów wyważonych z wyraźnym okazywaniem krytycyzmu dla projektów „efektownych”, które dają wprawdzie wrażenia fajerwerkowe, ale niczego nie zmieniają na lepsze.

Jaką rolę mogą odegrać pedagodzy akademiccy z udziałem ludzi PTP jako propagatorzy - tłumacze edukacyjni? Unikając oświeceniowych uproszczeń, powiedzmy, że może to być rola inicjatorów ciągłego namysłu, dyskusji i publicznych debat tematycznych możliwych - wbrew trudnościom - do przeprowadzenia, co przykładowo zademonstrował Zamojski swoimi pracami w Uniwersytecie Gdańskim w latach 2009-2010 (Zamojski 2010, 2011).

Obecny stan wymaga naszej nieustającej refleksji nad jakością i zakorzenieniem całości edukacyjnej oraz nad jej perspektywami, ale także namysłu nad działalnością samego Towarzystwa. Tymczasem PTP, jak to sformułowała jedna z jego członkiń, „[...] jakby się zatrzymało”. Powtarza się bowiem utarte już rozwiązania i reprodukuje dawne pomysły, głównie z pionierskich czasów, kiedy najważniejsze było stawianie nowych problemów demokratyzacji edukacji, a my potrafiliśmy utrzymywać zgodność treści i form prowadzonych działań. Obecnie zmieniają się treści zagadnień, jakie trzeba podejmować, co wypływa z zaostrzeń 
kryzysów, zagrożeń dla demokracji i wynikających stąd komplikacji edukacyjnych, a nieomal takie same pozostają formy naszych prac. Jeśli wprowadza się nowości, to dotyczą one bardziej rozwiązań organizacyjno-technicznych niż merytorycznych, a więc nie sięgają do sedna spraw jako owych, nazwanych przez Witkowskiego, „Zagrożeń zasadniczych”. Źródła gorących problemów dzisiejszej edukacji nie są niewinne, stanowią je bowiem napięte, konfliktowe stany społeczne, polityczne, ekonomiczne, kulturowe gwałtownie zagęszczającej się rzeczywistości. Niedostrzeganie ich jako gruntu osadzenia edukacji, umiarkowane tylko łączenie kwestii edukacyjnej z wielkimi kwestiami współczesności, atomizowanie podejmowanej tematyki powoduje niedocenianie sprawy jakości edukacji jako znaczącej dla całości społecznej. Owocuje to automarginalizacją pedagogów jako lokowaniem samych siebie, jak również uprawianych przez nich zagadnień pedagogicznych na poboczach, a nie w głównych nurtach życia, które edukacji dotyczą niezależnie od tego, czy my obdarzamy je naszą uwagą.

Wysuniętą hipotezę automarginalizacji zilustruję jednym przykładem. Jego część stanowi temat zbliżającego się kolejnego Ogólnopolskiego Zjazdu Pedagogicznego PTP w Białymstoku, zawarty w haśle „Ku życiu wartościowemu. Idee - koncepcje - praktyki”, rozwinięty w tytułach dziesięciu zjazdowych sekcji udostępnionych w sieci (9zjazd.ptp.uwb.edu.pl). Wyrażono je językiem patetycznym, postulatywnym, szczytnym, wzniosłym, nawiązującym do wielkiego bytu, językiem odległym od realiów trudnej, wręcz kipiącej dzisiejszej rzeczywistości. Wywołuje to skojarzenie z fragmentem Wesela Stanisława Wyspiańskiego:

tak by się nam serce śmiało

do ogromnych, wielkich rzeczy,

a tu pospolitość skrzeczy...

(W okresie międzywojennym ostatni wiersz uległ dziennikarskiemu przekształceniu na: „A tu rzeczywistość skrzeczy” i fraza zyskała popularność w tym brzmieniu).

Obrazy naszej rzeczywistości, także potraktowane w niniejszym eseju jako przykładowe, znalazłam ostatnio w tomie reportaży Marcina Kąckiego, sięgając do głębokich kontekstów spraw, jakie poruszył. W kilku przekrojach tematycznych spenetrował współczesny Białystok (miejsce zbliżającego się kolejnego zjazdu pedagogicznego). Przedstawił on miasto po gwałtownej zmianie kulturowo-etnicznej, na której gruzach budowała się po wojnie, i nadal buduje się, jego nowa tożsamość (Kącki 2015); opis ten odebrałam jako symboliczny i postawiłam sobie pytanie: na ile wychodzi on poza lokalność i oddaje stan kraju? Pomijając szczegółową treść reportaży, zwrócę porównawczo uwagę na różnice języków dwóch tekstów - dokumentu PTP, przygotowanego na zjazd naukowy, i reporterskiej, udokumentowanej, językowej charakterystyki samego zjazdowego miejsca - jego przeszłości i teraźniejszości, wydarzeń i nastrojów, z nazwiskami rozmówców, datami, instytucjami, odwołaniami do materiałów, listów, pamiątek. Otóż z książki Kąckiego wyłania się: 
- miejsce, które albo nie ma znaków pamięci, albo ma pamięć żywą, lecz uśpioną, czyli bez takiej historii, o której mówi się i dyskutuje w szkołach, a uczniowie rozmawiają z nauczycielami;

- tygiel wielu kultur ze śladami zasobów kulturowych (niektóre głęboko zasypane i to dosłownie), ale ze znikomą świadomością całości tego dziedzictwa;

- miejsce ciągle żywych historycznych zaszłości w stosunkach grup etnicznych, narodowych, religijnych, wyznaniowych dawniej żyjących tutaj względnie harmonijnie, a później - przez wiele lat, w napięciu i dramatach ujmowanych we wstrząsające relacje i "piekielne wspomnienia” (Kącki 2015: 36);

- miejsce losów niedopowiedzianych, biografii zapętlonych, z traumą ciągle obecną, z tragicznymi wspomnieniami holocaustu, czasów nie tylko powojennych, ale i współczesnych;

- miejsce „zapiekłych konfliktów” (Kącki 2015:36) i ostrych sporów o: pomniki, patrona uniwersytetu, teatr, muzykę, która zyskała tam popularność, o ludzi, znaki, słowa, symbole, szanse dla cudzoziemców;

- rodzinne miasto Ludwika Zamenhofa, którego idea ludzkiej zgody, zawarta w języku esperanto, „[...] została w 1977 roku wyryta na złotej płytce i umieszczona w sondzie Voyager, z pozdrowieniami dla obcej cywilizacji. Sonda minęła Układ Słoneczny, jest dwadzieścia miliardów kilometrów od Białegostoku i ciągle się oddala..." (Kącki 2015: 281), ale Zamenhofa nie uznano za godnego patrona tutejszego uniwersytetu;

- miejsce prowadzenia w tamtejszej Akademii Medycznej pionierskich prac medycznych w zakresie in vitro;

- lokalizacja jedynej w kraju uniwersyteckiej pracowni zajmującej się cudami (Pracownia Badań i Dokumentacji Zjawisk Mirakularnych (Kącki 2015: 269).

Zebranie zagadnień stanowiących główne tematyczne wątki przywołanego zbioru reportaży doprowadza do pytania: na ile wymowa tych lokalnych zapisów przybliża się do oddania jakości dzisiejszej ogólnopolskiej rzeczywistości, szczególnie jej niespójności, oraz, jeżeli na postawione pytanie udzielimy odpowiedzi pozytywnej, jak w warunkach takiej rzeczywistości można i należy uprawiać prace na rzecz prorozwojowej i prospołecznej edukacji.

Uczestnicy reporterskich narracji Kąckiego nierzadko mówią językiem (albo mówią o języku) nietolerancji, niechęci, ambiwalencji między nienawiścią a ludzką pomocowością, sięgającym jeszcze czasów wojny, ale występującym także dziś. Obecnie jest to często język uprzedzeń, oburzenia, agresji, wrogości, ksenofobii, język konfliktów, polaryzacji, podejrzeń dzielących ludzi różnych grup zróżnicowanych ideologicznie, etosowo, statusowo, instytucjonalnie. Niekiedy ma on formę pełnych, emocjonalnych wypowiedzi, a niekiedy strzępów narracji lub odmowy rozmowy z reporterem, przemilczania wydarzeń w nastroju obaw i czujności.

Dwie przyczyny wywołały moje zainteresowanie tymi odmiennymi tekstami i ich różnymi językami. Jedna łączy się z sygnalizowanym już odczuciem, że tonacja 
tekstu Kąckiego oddaje coś więcej niż relacje z problemów konkretnego miejsca jako miejsca zjazdowego, gdyz - w pewnym przynajmniej stopniu - oddaje nastroje występujące w kraju, którego bolesne zaszłości historyczne, polityczne i kulturowe, aktualizujące się z wielu powodów, nadal uwierają ludzi różnych miejsc sceny społecznej. Wywołuje to napięcia, wzajemne oskarżenia, trudności porozumiewania się, niemożność zrównoważonego dyskutowania i tworzenia konstruktywnych wspólnotowych projektów i rozwiązań rozwojowych, obejmujących także edukację.

Jeżeli wysunięta teza jest do przyjęcia, to trzeba by daną kwestię, oddającą aktualny stan jako szczególnie trudny, uwzględniać w problematyce Zjazdu. Tymczasem Zjazd ma spolegliwy temat i projekt programowy wyprowadzony jakby $\mathrm{z}$ innego świata życia.

Druga przyczyna mojego zainteresowania przywołanymi tekstami wynika z różnic języków, jakimi mówi się o podejmowanych zagadnieniach. Język przedzjazdowy, występujący w odpowiednich dokumentach jest poprawny, standardowy, wzniosły, estetyczny (nie wiemy, jaki będzie język zjazdowy), natomiast język realiów codzienności jest napięty, dobitny, wyrazisty, radykalny, nierzadko brutalny. Używanie w przedzjazdowej dokumentacji PTP języka o tonacji bardzo odległej od gorących, arcytrudnych problemów realnej, aktualnej rzeczywistości powoduje, że tworzy się swojego rodzaju nowe "nieobecne dyskursy" w tym sensie, że mówi się o tym, co nie jest obecnie najtrudniejsze dla naszej edukacji , a omija się i unika „dyskursów obecnych”, w których mówi się o „pedagogice wstydu”, „pedagogice dumy”, ,jedynej prawdzie”, wychowawczej „polityce historycznej”, „nowym patriotyzmie”, „Polsce dla Polaków”, co wyraża treści i projekty wychowania wyraźnie merytorycznie ukierunkowane, ale wyrażające krańcowo różne odbiory ludzi - od głębokich niepokojów do butnego entuzjazmu.

Ten stan wymaga przemyśleń oraz odpowiedzialnych dyskusji z użyciem wypracowanych argumentów i kontrargumentów, słowem - dokonania przepracowania kulturowego, o jakim już wspomniano. My natomiast, pomijając najgorętsze tematy sytuacji trudnej, wytwarzamy drugi wariant „nieobecnych dyskursów". Dawniej tworzył je nam izolacyjny system, w którym musieliśmy zdobywać niedostępną wiedzę, natomiast obecnie tworzymy je my sami, nie stawiając przed sobą i wobec sfery publicznej palących, szczególnie aktualnych kwestii edukacyjnych, które zastępuje się ciszą tematyczną przysłoniętą językową formą, wprawdzie brzmiącą poprawnie, ale czy znaczącą?

Jak my, ludzie Polskiego Towarzystwa Pedagogicznego, możemy znaleźć się w tej sytuacji?

Jestem zdania, że podpowiedzi warto szukać $\mathrm{w}$ zwróceniu się ku zaniedbanym zobowiązaniom statutowym, dotyczącym popularyzacji, a dokładniej - upubliczniania wiedzy pedagogicznej przez wprowadzanie na fora publiczne tematyki edukacyjnej jako tematyki społeczno-etycznej z weryfikowaniem obiegowych uproszczeń, ze wskazywaniem na kontekstowe zanurzenia, perspektywiczne znaczenia, na szeroko pojętą rozwojową wagę i powagę edukacji, a także na jej realizacyjne komplikacje. 
Jak to robić? Jest to temat wymagający solidnego namysłu nad kierunkiem dalszych prac i rozwoju Polskiego Towarzystwa Pedagogicznego, a być może i szerzej - namysłu nad perspektywami działalności towarzystw naukowych w dzisiejszym czasie trudnym.

Aby relacyjnie powiązać myślenie programowe z realiami rzeczywistości (a więc, aby nie tworzyć nowego „nieobecnego dyskursu”), trzeba przyjrzeć się kryzysowej sytuacji, w jakiej obecnie jesteśmy. Przyjmijmy, że kryzys polegający na „[...] zakłóceniu stosunku między horyzontem oczekiwania a przestrzenią doświadczenia" (Ricoeur 1990: 53) nie jest zarazem zapaścią bądź trudnością rujnującą rzeczywistość do dna, tylko przełomem prowadzącym do nowej jakości, w „narodzinach” której szczególną rolę odgrywa język (Mendel, Szkudlarek 2013).

Kierując się tym założeniem, proponuję zintensyfikowane dopełnianie dotychczasowego naukowego kierunku prac prowadzonych przez Towarzystwo realizowaniem drugiej linii statutowych zobowiązań, dotyczącej prowadzenia popularyzacji - jako upubliczniania wiedzy o edukacji, służącej realizowaniu opiniotwórczej i kulturotwórczej funkcji Towarzystwa przez alfabetyzację edukacyjną.

Alfabetyzację edukacyjną pojmuję jako prace językowe realizowane w formach czuwania nad językiem edukacji, pielęgnowania wrażliwości semantycznej podmiotów edukacyjnych, szukania i tworzenia języka odpowiadającego treściom prezentowanych problemów pedagogicznych, wnikania w sensy tego, o czym mówimy, alarmowania w sytuacjach nadużyć językowych, uwrażliwiania siebie i otoczenia na konsekwencje zmieniania znaczeń oraz najszerzej - na społeczno-językowe tworzenie rzeczywistości, także edukacyjnej.

O znaczeniu zmieniania sensów w zakresie edukacji niech zaświadczy aktualny przykład zaczerpnięty z badań Łukasza Stankiewicza, który wykazał, jak różne interpretowanie postaci studenta $\mathrm{w}$ dokumentach reformowania uczelni stanowi podstawę budowania i uzasadniania zupełnie różnych modeli kształcenia na poziomie wyższym (Stankiewicz 2012: 246-247). Sprawa ta mieści się w obszarze nienowego, ale ostatnio zaostrzonego zagadnienia politycznego manipulowania językiem (Bihr 2008).

Dla przybliżenia postulatu podejmowania alfabetyzacyjnych prac językowo-edukacyjnych wspomnę, w formie trzech przykładów, o dynamice aktualnego używania języka i jej konsekwencjach. Słowo „wielokulturowość”, które przez długi czas budziło nadzieje rozumienia odpowiedniego aspektu złożoności rzeczywistości, ostatnio staje się niewystarczające dla ogarniania problemów w całej gamie ich komplikacji, trzeba więc podjąć wysiłki językowe niejako od nowa.

Zwrot „przepracować przeszłośc” jest używany przez autorów tekstów społeczno-historycznych, niekiedy też i pedagogicznych, ale czy jasne jest, co on właściwie znaczy i na czym polega takie przepracowanie, jakie rzeczywiście może sprzyjać świadomościowym przebudzeniom uczestników wydarzeń.

Przykład trzeci, tym razem konstruktywny, dotyczy zwrotu "nauczyciel ignorant”, wprowadzonego przez Jacques'a Rancièra. Nie oznacza on niewiedzy nauczyciela, 
tylko przyjmowanie przez niego nieprawdziwego założenia o równych poziomach inteligencji (jako poznawczych możliwościach) jego uczniów. Tę hipotezę poddaje się weryfikacji, ale nieosadzonej w klasycznej procedurze pozytywistycznej metodologii, lecz takiej, gdzie jest ona traktowana jako podstawa pracy pedagogicznej, prowadzonej ku czynieniu owych założeń prawdziwymi (Rancière 1991).

Dla mnie książka Rancièra i określenie „nauczyciel-ignorant” stanowiła orzeźwiającą lekturę sprzyjającą podejmowaniu prób nadawania innego sensu mojemu współdziałaniu z masowymi studentami, z którymi pracuję. Zauważyłam, że przyjęcie odpowiedniej, kontrfaktycznej tezy dało mi szanse osłabiania oburzenia na jakość ich słabego przygotowania do studiowania i wzmacniania mojej motywacji do pracy z młodymi ludźmi o bardzo zróżnicowanych poziomach, co sprzyja osiąganiu postępów w pracy dydaktycznej, chociaż bywają to postępy inne niż te, jakie sobie wstępnie wyobrażałam.

Proponuję, aby sugerowane prace językowe, widziane jako nasz wkład do intensyfikowania oddziaływań kulturotwórczych i opiniotwórczych PTP, ulokować w trzech obszarach:

- leksykalnym;

- namysłu nad „pustymi znaczącymi” (według Laclau);

- wartościowania terminów znaczeniowo pustych, ale istotnych dla tworzenia wizji świata pożądanego (według Szkudlarka).

Prace w obszarze leksykalnym dotyczyłyby naszego wkładu w rozbudowę obywatelskich edukacyjnych zasobów słownikowych służących usprawnianiu myślenia i publicznego mówienia o edukacji oraz zapobieganiu dezorientacji semantycznej w tym obszarze; $\mathrm{w}$ istocie chodziłoby o podnoszenie poziomu kultury pedagogicznej społeczeństwa. Może temu służyć rekonstruowanie zasobów merytorycznych znaczeń z obszaru edukacji, identyfikowanie zróżnicowanych stanowisk edukacyjnych z pogłębianiem ich uzasadniania, myślowe cywilizowanie projektów i wypowiedzi przez akcentowanie wagi świadomego namysłu nad tym, o czym się mówi i na czym polega odpowiedzialność za mowę. Nie idzie więc o lekcje „słusznych znaczeń", ale o udostępnianie i uprzystępnianie instrumentarium językowego umożliwiającego lepszą komunikację prowadzącą do merytorycznie konstruktywnego namysłu i odpowiedzialnego projektowania rozwiązań edukacyjnych oraz uprawiania rzeczowej krytyki odnośnie do uzyskiwanych wyników.

Podobny pomysł dotyczący innej dziedziny, autorstwa Radosława Markowskiego, zasygnalizowano ostatnio $\mathrm{w}$ prasie. Umieszczając teksty pod nośnym tytułem Sprostowania, autor zamierza przedstawić cykl materiałów stanowiących politologiczną pomoc dla odpowiedzialnego obywatela, który „[...] interesuje się sprawami publicznymi, sprawdza, jak się rzeczy mają w realu, czyta, aby nie poddać się arogancji i pogardzie dla rozumu". W cyklu tym będzie się prezentować czytelnikom zawartość podstawowego słownika społeczno-obywatelskiego z uwzględnieniem pojęć: 1) demokracji, 2) państwa prawa i konstytucjonalizmu, 3) kapitalizmu XXI wieku i wzorów z państwa dobrobytu, 4) zagadnienia Unia Polska. Celem prezentacji będzie wspomaganie ludzi w tym, aby mogli z lepszym 
rozumieniem odbierać treści dotyczące życia społecznego, komentować je, dyskutować o nich, sprawnie myśleć i komunikować się dla planowania i realizowania działań wspólnych (Markowski 2016: 19).

Proponowane dalej, jako możliwy kierunek dla PTP, pedagogiczne prace językowe w obszarze namysłu nad „pustymi znaczącymi” dotyczyłyby zarówno wyobrażeń i nazywania ich, jak i wypełniania ich znaczeniami. Dzięki sensom wypełniającym owe obszary moglibyśmy tak budować imaginarium edukacyjne, aby zobaczyć kwestię edukacyjną w nowych dla nas oświetleniach językowych i dzięki temu pogłębiać własny namysł nad dziedziną, którą uprawiamy, co komplikuje się w warunkach funkcjonowania wielu pedagogii.

Na marginesie zasygnalizuję, że najbliższy XVI Zjazd Polskiego Towarzystwa Socjologicznego (wrzesień 2017) odbył się pod hasłem „Solidarność w czasach nieufności”. Solidarność występująca tutaj jako, wielokrotnie już komentowana w literaturze, „pusta znacząca” stanowi przykład, jak tego rodzaju element może być poręczny dla prowadzenia namysłu społeczno-naukowego.

Trzeci obszar prac proponowanych do podjęcia przez Towarzystwo dotyczy treści jako wartościowania terminów znaczeniowo pustych. W obawie przez ideologizowaniem zagadnień odnosimy się do wartościowania z nieufnością, ale subtelną inspirację dla tej sprawy podał niedawno Szkudlarek w sprawozdaniu $\mathrm{z}$ badawczego projektu o dyskursywnej konstrukcji podmiotu (Szkudlarek et al. 2012). Nawiązując do pedagogiki kultury i eksponując jednostkę jako podmiot „kształtowalny”, autor zwrócił się ku kwestii wartościowania tego, co potencjalnie może być, chociaż nie jest, wypełnione wartościami. Postrzegając tę kwestię jako paradoksalną (Szkudlarek et al. 2012: 13-16), gdyż mówi o pustym/niepustym, zarazem podejmuje ją i chroni klasycznym uzasadnieniem o obowiązywaniu wartości, jakie „[...] oddają wizje świata, którego nie ma, ale być powinien”. Taka "figura" tworzy - ciągle bliski pedagogom - deontyczny układ powinnościowy, w pewnym sensie bliski „pustym znaczącym” jako fenomenom lokowanym „[...] ponad sferą tożsamości i poza sferą doświadczenia” (Szkudlarek et al. 2012: 17). Jest to układ jakby aktualnie nieznaczący, ale jednocześnie znaczący jako możliwy, a nawet powinnościowo „pożądany”, a myślenie o takim świecie zawsze było domeną pedagogów.

Podsumowując tę wypowiedź o działalności Polskiego Towarzystwa Pedagogicznego w 35-lecie jego działalności, podkreślę raz jeszcze poważny wkład ludzi Towarzystwa w cały myślowy ruch dotyczący problematyki edukacji i jej przemian związanych z przełomem systemowym i współczesnymi przemianami kultury. W swojej niedawnej prezentacji „pedagogiki po przejściach” z akcentem postawionym na pozytywy Kwieciński przedstawił nasze naukowe osiągnięcia także z uwzględnieniem wkładu środowiska PTP. Zarazem autor zwrócił uwagę, że pomimo podjętych przez Towarzystwo prób zbudowania pożądanych relacji między pedagogiką a sferą publiczną, „[...] Nie zaistniało jednak w Polsce środowisko i instytucje, które kształtowałyby strategiczną, systemową, paradygmatyczną wizję rozwoju edukacji [...]” (Kwieciński 2011: 24). 
Na postawione w niniejszym tekście pytania: „Co dalej? W którą pójść stronę?” proponuję kierunek językowy, stwarzający szanse alfabetyzacji edukacyjnej jako pracy podstawowej dla budowania wspólnotowego fundamentu strategicznej wizji edukacji prorozwojowej, jako dobrej dla ludzi i czasów - zawsze niełatwych.

Określenia „czas trudny”, występującego w tytule niniejszego eseju, nie łączę bowiem z okresami wyjątkowo niekorzystnymi dla podejmowanych przedsięwzięć, widzę je natomiast jako zjawisko ciągle obecne, wynikające z komplikacji świata i edukacji, ale stanowiące też dla ludzi czynnik mobilizacji. W 35-letniej działalności naszego Towarzystwa atmosfera mobilizacyjna występowała ze zmiennym nasileniem. Ostatnio optymistycznie świadomi dużej pracy, jaką wykonaliśmy na rzecz edukacji, ale zarazem zorientowani w jakości krajowej oświaty, daleko niesatysfakcjonującej społecznie, czujemy się też rozczarowani i przygnębieni. Dla podniesienia koleżeńskiego nastroju, wbrew czasom trudnym, przywołuję fragment utworu Cypriana Kamila Norwida Cywilizacja

Co dzień woda w okręt ciecze,

Nogą z łoża ani stąp;

Co wieczora - o! Człowiecze,

W górę rękaw! - i do pomp.

Rzecz w tym, że tę „pompę” my sami musimy myślowo skonstruować.

\section{Literatura}

Arendt A., 2000, Kondycja ludzka, tłum. A. Łagodzka, Warszawa: Fundacja Aletheia. Bartosik P., 2013, Kulturotwórcza rola Towarzystw Naukowych Ogólnych w XIX wieku na przykładach: Towarzystwa Naukowego Krakowskiego, Towarzystwa Naukowego Płockiego, Towarzystwa Naukowego Krakowskiego oraz Towarzystwa Naukowego w Toruniu, „Studia Sieradzana” nr 3, bazhum.muzhp.pl/media [dostęp: 12.05.2016].

Bauman Z., 1998, Prawodawcy i tłumacze, tłum. A. Ceynowa, J. Giebułtowski, Warszawa: Wydawnictwo IFiS PAN.

Bihr A., 2008, Nowomowa neoliberalna. Retoryka kapitalistycznego fetyszyzmu, tłum. A. Łukomska, Warszawa: Instytut Wydawniczy Książka i Prasa.

Cierzniewska R., 2011, Wokót przemian akademickiego środowiska pedagogów w Polsce, Bydgoszcz: Wydawnictwo Uniwersytetu Kazimierza Wielkiego.

Crouch C., 2015, Osobliwa nie-śmierć neoliberalizmu, tłum. Ł. Dominiak, Toruń: Wydawnictwo Naukowe UMK.

Czerepaniak-Walczak M. (red.), 2013, Fabryki dyplomów czy universitas?, Kraków: Impuls. Dobrołowicz J., 2013, Obraz edukacji w polskim dyskursie prasowym, Kraków: Impuls.

Dudzikowa M., Knasiecka-Falbierska K. (red.), 2013, Sprawcy i/lub ofiary działań pozornych w edukacji szkolnej, Kraków: Impuls.

Folkierska A., 1990, Pytanie o pedagogike, Warszawa: Wydawnictwa Uniwersytetu Warszawskiego. 
Hejnicka-Bezwińska T., 1997, Tożsamość pedagogiki. Od ortodoksji do heterogeniczności, Warszawa: Wydawnictwo'69.

Hejnicka-Bezwińska T., 2011, Podobieństwa i różnice w ujawnianiu i przezwyciężaniu kryzysów polskiej pedagogiki XX wieku [w:] Pedagogika. Zakorzenienie i transgresja, red. M. Nowak-Dziemianowicz, P. Rudnicki, Wrocław: Wydawnictwo Naukowe Dolnośląskiej Szkoły Wyższej.

Hornowska E., 2003, O pomiarze jakości usług w obszarze edukacji [w:] Ocena wewnętrzna i zewnętrzna jakości kształcenia w szkołach wyższych, red. J. Brzeziński, A. Eliasz, Warszawa: Wydawnictwo SWPS Academica.

Jaworska-Witkowska M., Kwieciński Z., 2011, Nurty pedagogii. Naukowe, dyskretne, odlotowe, Kraków: Impuls.

Kącki M., 2015, Białystok. Biała siła, czarna pamięć, Wołowiec: Wydawnictwo Czarne.

Klus-Stańska D., 2006, Doświadczenia pedagogiczne nauczycieli jako źródło ich niezdolności do refleksji nad własna aktywnościa zawodowa [w:] Sapientia et adiumentum. W trosce o rozwój innych. Studia dedykowane profesorowi Zbigniewowi Kwiecińskiemu, red. J. Michalski, Olsztyn: Uniwersytet Warmińsko-Mazurski.

Kopciewicz L., 2012, Pedagogika krytyczna dziś?, „Ars Educandi” t. 9: Pedagogika krytyczna dziś. Podstawy, dylematy i wybrane problemy.

Koralewicz J., Ziółkowski M., 2003, Mentalność Polaków. Sposoby myślenia o polityce, gospodarce i życiu społecznym 1988-2000, Warszawa: Wydawnictwo Naukowe SCHOLAR/Collegium Civitas Press.

Kruszelnicki M., 2011, Uniwersytet jako wspólnota audytowanych [w:] Przeszkody dla rozwoju humanistyki $w$ szkołach wyżsych ( $z$ pedagogika $w$ tle). W perspektywie troski o uniwersytet, kulturę humanistyczna i podręczniki, red. M. Jaworska-Witkowska, L. Witkowski, Toruń: Wydawnictwo Adam Marszałek.

Kwaśnica R., 1990, Ukryte założenia trzech krytyk. Przyczynek do samowiedzy pedagogii przejścia i pogranicza [w:] Ku pedagogii pogranicza, red. Z. Kwieciński, L. Witkowski, Toruń: UMK.

Kwieciński Z., 1982, Edukacja demokratyczna i humanistyczna jako ruch i dzieło społeczne, „Socjologia Wychowania” t. 4.

Kwieciński Z., 1990, Pedagogika i edukacja wobec wyzwania kryzysu i gwałtownej zmiany społecznej [w:] Ku pedagogii pogranicza, red. Z. Kwieciński, L. Witkowski, Toruń: UMK.

Kwieciński Z., 1994, „Mimikra czy sternik? Dramat pedagogiki w sytuacji przesilenia formacyjnego [w:] Ewolucja tożsamości pedagogiki, red. H. Kwiatkowska, Warszawa: PTP.

Kwieciński Z., 1996, Konflikt uspołecznienia i etatyzacji $w$ wychowaniu (w warunkach przesilenia i zmiany społecznej) [w:] Wprowadzenie do pedagogiki. Wybór tekstów, red. T. Jaworska, R. Leppert, Kraków: Impuls.

Kwieciński Z., 1997, Pedagogika i edukacja na przedprożu nowego wieku [w:] Wybrane problemy pedagogiki polskiej po roku 1989, red. H. Kwiatkowska, Z. Kwieciński, Toruń: PTP.

Kwieciński Z., 2011, Pedagogika po przejściach - aspekty pozytywne [w:] Pedagogika. Zakorzenienie i transgresja, red. M. Nowak-Dziemianowicz, P. Rudnicki, Wrocław: Wydawnictwo Naukowe Dolnośląskiej Szkoły Wyższej.

Kwiek M., 2015a, Podzielony uniwersytet. Od deinstytucjonalizacji do reinstytucjonalizacji misji badawczej polskich uczelni, „Nauka i Szkolnictwo Wyższe” nr 2. 
Kwiek K., 2015b, Uniwersytet $w$ dobie przemian. Instytucje $i$ kadra akademicka $w$ warunkach rosnacej konkurencji, Warszawa: Wydawnictwa Naukowe PWN.

Leder A., 2013, Prześniona rewolucja. Ćwiczenia z logiki historycznej, Warszawa: Wydawnictwo Krytyki Politycznej.

Lewowicki T., 1997, O dorobku pedagogiki po roku 1989 [w:] Wybrane problemy pedagogiki polskiej po roku 1989, red. H. Kwiatkowska, Z. Kwieciński, Toruń: Edytor.

Markowski R., 2016, Czas obywatela, „Gazeta Wyborcza”, 25-26.06.

Mendel M., Szkudlarek T., 2013, Kryzys jako dyskurs i narracja. Konteksty edukacyjne, „Forum Oświatowe” nr 3.

Ossowska M., 1992, Wzór demokraty, Lublin: Daimonion Instytut Wydawniczy.

Piketty T., 2015, Kapitał w XXI wieku, tłum. A. Bilik, Warszawa: Wydawnictwo Krytyki Politycznej.

Pilch T., 2004, Bezradność czy zaniechanie - usprawiedliwieni czy winni? Pedagogowie w czasach potrzeby? [w:] Nauki pedagogiczne w Polsce. Dokonania, problemy, wspótczesne zadania, perspektywy, red. T. Lewowicki, M.J. Szymański, przy współpracy R. Kwiecińskiej, S. Kowala, Kraków: Wydawnictwo Naukowe Akademii Pedagogicznej.

Potulicka E., 2012a, Pytania o skutki neoliberalizmu. Aspekt jednostkowy [w:] E. Potulicka, J. Rutkowiak, Neoliberalne uwikłania edukacji, Kraków: Impuls.

Potulicka E., 2012b, Pytania o skutki neoliberalizmu. Aspekt społeczny [w:] E. Potulicka, J. Rutkowiak, Neoliberalne uwikłania edukacji, Kraków: Impuls.

Potulicka E., Rutkowiak J., 2012, Neoliberalne uwikłania edukacji, Kraków: Impuls.

Rancière J., 1991, The Ignorant Schoolmaster. Five Lessons in Intellectual Emancipation, California: Stanford University Press.

Raport: „Polska 2050”, 2011, Warszawa: Polska Akademia Nauk, Komitet Prognoz „Polska 2000 Plus".

Ricoeur P., 1990, Kryzys - zjawisko swoiście nowoczesne [w:] O kryzysie, przygotował i przedmową opatrzył K. Michalski, Warszawa: Res Publica.

Rodziewicz E., 2008, Ku demokracji w sferze publicznej i dyskursie edukacyjnym. Polskie Towarzystwo Pedagogiczne Oddział w Gdańsku wobec zmiany społecznej, „Ars Educandi" t. 5, red. E. Rodziewicz.

Rutkowiak J., 1997, Między upaństwowieniem, prywatyzacja i uspołecznianiem się pedagogiki [w:] Wybrane problemy pedagogiki polskiej po roku 1989, red. H. Kwiatkowska, Z. Kwieciński, Toruń: PTP.

Rutkowiak J., 2012, Nauczyciel interpretatorem edukacyjnej rzeczywistości neoliberalnej [w:] E. Potulicka, J. Rutkowiak, Neoliberalne uwikłania edukacji, Kraków: Impuls.

Rutkowiak J., Kubinowski D., Nowak M. (red.), 2007, Edukacja - moralność - sfera publiczna. Materiały z VI Ogólnopolskiego Zjazdu Pedagogicznego PTP, Lublin: Oficyna Wydawnicza „Verba”.

Skarga B., 2007, O obywatelstwie. Wykład wygłoszony z okazji inauguracji roku akademickiego 2005/2006 w Uniwersytecie w Białymstoku [w:] B. Skarga, Człowiek to nie jest piękne zwierzę, „Znak” nr 1.

Sowa J., 2011, Fantomowe ciało króla. Peryferyjne zmagania z nowoczesną formą, Kraków: Universitas. 
Stankiewicz Ł., 2012, Pozycja studentów w uniwersytecie przyszłości - analiza wybranych dokumentów z debaty nad reforma szkolnictwa wyższego, „Ars Educandi”, t. 9: Pedagogika krytyczna dzis. Podstawy, dylematy i wybrane problemy.

Statut Polskiego Towarzystwa Pedagogicznego z 11 maja 2016 roku ze zmianami z 6 czerwca 2017 roku.

Szkudlarek T., 2012, Wstęp [w:] M. Cackowska et al., Dyskursywna konstrukcja podmiotu. Przyczynek do rekonstrukcji pedagogiki kultury, Gdańsk: Wydawnictwo Uniwersytetu Gdańskiego.

Szwabowski O., 2014, Uniwersytet. Fabryka. Maszyna. Uniwersytet w perspektywie radykalnej, Warszawa: Instytut Wydawniczy „Książka i Wiedza”.

Walicki A., 2013, Od projektu komunistycznego do neoliberalnej utopii, Kraków: Universitas Polska Akademia Nauk.

Witkowski L., 2010, Tożsamość i zmiana. Epistemologia i rozwojowe profile w edukacji, Wrocław: Wydawnictwo Naukowe DSW.

Witkowski L., 2012, Wokół pedagogiki krytycznej (retrospekcja i projekcja na tle problemów i doświadczeń w pedagogice polskiej), „Ars Educandi”, t. 9: Pedagogika krytyczna dziś. Podstawy, dylematy i wybrane problemy.

Zamojski P., 2010, Pytanie o cel kształcenia - zaproszenie do debaty, Gdańsk: Wydawnictwo Uniwersytetu Gdańskiego.

Zamojski P., 2011, Pomyśleć szkołe inaczej. Edukacja matematyczno-przyrodnicza w toku debat publicznych, Gdańsk: Fundacja Rozwoju Uniwersytetu Gdańskiego.

IX Ogólnopolski Zjazd Pedagogiczny „Ku życiu wartościowemu. Idee - koncepcje - praktyki”, 9zjazd.ptp.uwb.edu.pl

\begin{abstract}
Abstrakt
Strukturę eseju tworzy pytanie o realizację statutowych celów działania PTP, analogicznych wobec celów innych towarzystw naukowych. Dotyczą one uprawiania i popierania badań naukowych przez udział członków w rozwoju odpowiednich dyscyplin oraz propagowania uzyskiwanych wyników i społecznego popularyzowania osiągnięć poznawczych. Przegląd wybranych elementów 35 lat działalności Towarzystwa daje podstawę do konstatacji, że uzyskano sukcesy w zakresie badań naukowych i publikacji, natomiast niewystarczająco realizowano cel społecznego obiegu myśli pedagogicznej sprzyjającej zmianie edukacji pojmowanej jako ruch i dzieło społeczne. Perspektywy rozwoju Polskiego Towarzystwa Pedagogicznego dostrzega autorka w uprawianiu „alfabetyzacji edukacyjnej”.
\end{abstract}

\title{
Słowa kluczowe
}

popieranie badań, upowszechnianie wiedzy, uspołecznienie 


\section{Summary}

Scientific association in hard times; an essay on the 35th anniversary of the Polish Pedagogical Association

The structure of the essay is created with a question about realization of Statutory goals of PTP in the context of other scientific societies. It concerns conducting and popularizing scientific research and promotion of scientific achievement. The review of 35 years of society's activities gives a conclusion that there was a success on the field of scientific research and publication of their result. At the same time, there is a significant lack of progress towards popularizing educational ideas and creating ground for educational change understood as social activity. Author of the text sees the perspectives for advancement of PTP in „alphabetization of education”.

Keywords

supporting research, dissemination of knowledge, socialization 